\title{
Usaha Ternak Sapi Perah di Kelompok Usaha Bersama (KUB) Tirtasari Kresna Gemilang: Identifikasi Sumber Daya dan Kajian Aspek Kerentanan
}

\section{Dairy Cattle Farming Business at the Joint Business Group (KUB) Tirtasari Kresna Gemilang: Resources Identification and Vulnerability Aspect Study}

\author{
Amam $^{1,2) *}$, Moh. Wildan Jadmiko1), Pradiptya Ayu Harsita ${ }^{1)}$, Roni Yulianto ${ }^{1)}$, \\ Nur Widodo ${ }^{1)}$, Soetriono2), Moh. Setyo Poerwoko ${ }^{3)}$ \\ ${ }^{1)}$ Department of Animal Husbandry, Faculty of Agriculture, University of Jember, \\ J1. Diponegoro, Bondowoso 68251 \\ ${ }^{2)}$ Department of Agribusiness, Faculty of Agriculture, University of Jember, \\ Jl. Kalimantan, Jember 68121 \\ ${ }^{3)}$ Department of Agronomy, Faculty of Agriculture, University of Jember, \\ Jl. Kalimantan, Jember 68121
}

Article history

Received: Jan 20, 2020;

Accepted: Mar 7, 2020

* Corresponding author:

E-mail:

amam.faperta@unej.ac.id

DOI: https://doi.org/10.46549 /jipvet.v10i1.90

\begin{abstract}
Resources have an important role in livestock farming business, while the aspect of vulnerability can hamper the development of livestock farming business. The purpose of this study is to identify the resources of dairy cattle farming business and examine its effects on the aspects of vulnerability. The resources of this study consisted of economic resources, environmental resources, and social resources. The research was conducted in June-September 2019 at the Joint Business Group (KUB) of Tirtasari Kresna Gemilang which is located in Malang District, East Java Province. The 174 respondents are all dairy farmers who are the members of the group. The data collection methods used are Focus on Group Discussion (FGD), observation, and survey. The survey method was carried out through interviews and questionnaires. Data were analyzed using the Partial Least Square (PLS) method. The results showed that the vulnerability aspect of dairy cattle farming business was positively and significantly affected by economic and environmental resources ( 0,249 and 0,317 , respectively). On the other hand, social resources had a negative influence, although it was not significant to the vulnerability aspect of dairy cattle farming business. The conclusion of the research shows that the aspect of the vulnerability of dairy cattle farming business is influenced by economic, environmental, and social resources by $29.5 \%$.
\end{abstract}

Keywords: Economical; Environmental; Social; Resources

\section{PENDAHULUAN}

Perubahan Peraturan Menteri Pertanian Nomor 26 tahun 2017 ke Peraturan Menteri Pertanian Nomor 33 tahun 2018 tentang Penyediaan dan Peredaran Susu, berdampak pada semakin beratnya persaingan Susu Segar Dalam Negeri (SSDN). Dampak tersebut berkaitan dengan kemitraan (Pasal 23-24) yang harus dilakukan oleh para pelaku usaha Industri Pengolahan Susu (IPS) dengan peternak, gabungan peternak, dan/atau koperasi melalui penyarapan dan pemanfaatan SSDN. Hal tersebut sebagai upaya untuk menekan laju impor susu segar dan peningkatan kesejahteaan peternak sapi perah.

Model kemitraan dengan menyerap dan memanfaatkan SSDN sejatinya merupakan suatu langkah strategis mengingat usaha peternakan sapi perah rakyat yang cenderung belum efisien. Rendahnya kualitas susu segar dan rendahnya akses peningkatan nilai tambah menyebabkan model kemitraan efektif untuk diterapkan di industri persusuan dalam negeri 
sesuai dengan Peraturan Menteri Pertanian Nomor 13 tahun 2017 tentang Kemitraan Usaha Peternakan.

Penerbitan Peraturan baru, yaitu Peraturan Menteri Pertanian Nomor 30 dan 33 tahun 2018 yang isinya tidak mewajibkan para pelaku usaha untuk menyerap dan memanfaatkan Susu Segar Dalam Negeri (SSDN) menjadi kendala tersendiri bagi pengembangan usaha ternak sapi perah rakyat. Salah satu upaya untuk meningkatkan kesejahteraan peternak ialah dengan melakukan pemberdayaan peternak sesuai dengan Peraturan Pemerintah Republik Indonesia Nomor 6 tahun 2013 tentang Pemberdayaan Peternak. Pemberdayaan peternak merupakan segala upaya yang dilakukan oleh pemerintah pusat, pemerintah provinsi, pemerintah kota/kabupaten, dan para pemangku kepentingan di bidang peternakan dan kesehatan hewan untuk meningkatkan kemandirian, memberikan kemajuan dan kemudahan usaha, serta meningkatkan daya saing dan kesejahteraan peternak.

Pemberdayaan tersebut salah satunya bertujuan untuk meningkatkan daya saing susu segar, meningkatkan nilai tambah peternak sapi perah, serta melakukan pengembangan usaha ternak sapi perah. Pengembangan usaha ternak sapi perah tidak terlepas dari aksesibilitas peternak terhadap sumber daya (Amam et al., $\left.2019^{a}\right)$. Sumber daya memiliki peranan penting terhadap pengembangan usaha ternak (Amam et al., 2019 ${ }^{\mathrm{b}}$ ). Sumber daya tersebut diantaranya ialah sumber daya finansial, sumber daya teknologi, dan sumber daya fisik (Amam et al., $2019^{c}$ ), juga sumber daya ekonomi, sumber daya lingkungan, dan sumber daya sosial (Amam et al., 2019 ${ }^{\mathrm{d}}$ ).

Kelembagaan peternak menjadi salah satu wadah yang ideal untuk pemberdayaan peternak sapi perah. Amam dan Soetriono (2019) menyebutkan bahwa kelembagaan peternak dapat berperan sebagai tindakan preventif untuk mengurangi risiko bisnis dan juga dapat berperan di dalam proses pengembangan usaha ternak. Risiko bisnis tersebut diantaranya yaitu menekan aspek kerentanan usaha ternak sapi perah. Amam dan Harsita $\left(2019^{a}\right)$ menjelaskan bahwa aspek kerentanan adalah kondisi bahaya (rentan), baik bahaya alami maupun bahaya buatan yang jika muncul (terjadi) dapat merugikan peternak sapi perah.

Aspek kerentanan dan pengembangan usaha dapat mempengaruhi Sumber Daya Manusia (SDM) peternak sapi perah (Amam dan Harsita, 2019 ${ }^{\mathrm{b}}$ ). Hal tersebut menunjukkan bahwa pentingnya peranan kelembagaan sebagai wadah pemberdayaan peternak. Pemberdayaan tersebut meliputi semua aspek usaha ternak, yaitu breeding, feeding, and management. Amam dan Harsita (2019') menyatakan bahwa terdapat tiga pilar utama di dalam usaha ternak, yaitu breeding, feeding, and management.

Kelembagaan sebagai wadah pemberdayaan peternak juga telah dilakukan di Kelompok Usaha Bersama (KUB) Tirtasari Kresna Gemilang. KUB Tirtasari Kresna Gemilang terletak di Kecamatan Pujon, Kabupetan Malang, Provinsi Jawa Timur. KUB tersebut memiliki anggota sebanyak 174 peternak sapi perah. Kantor KUB berada di Desa Ngabab dan merupakan salah satu kelembagaan peternak sapi perah yang sudah mempunyai izin legalitas yang sah dan berbadan hukum nomor 0010084-AH.01.07. Keputusan Menteri Pertanian Nomor 43 tahun 2015 menetapkan bahwa Kabupaten Malang merupakan salah satu Kawasan Peternakan Sapi Perah Nasional (KPSPN).

Penelitian ini bertujuan untuk mengidentifikasi aksesibilitas peternak sapi perah terhadap sumber daya ekonomi, lingkungan, dan sosial, serta mengkaji pengaruhnya terhadap aspek kerentanan usaha ternak melalui variabel antara, yaitu Sumber Daya Manusia (SDM) peternak sapi perah. Penelitian dilakukan pada bulan JuniSeptember 2019 di kelembagaan peternak sapi perah Kelompok Usaha Bersama (KUB) Tirtasari Kresna Gemilang, Kabupaten Malang.

\section{MATERI DAN METODE}

Lokasi penelitian ditentukan secara purposive sampling dengan pertimbangan bahwa Kabupaten Malang merupakan salah satu kawasan peternakan sapi perah nasional sesuai dengan Keputusan Menteri Pertanian Nomor 43/2015. Responden adalah semua peternak sapi perah anggota kelembagaan peternak sapi perah Kelompok Usaha Bersama 
(KUB) Tirtasari Kresna Gemilang. Jumlah responden sebanyak 174 orang.

Metode pengumpulan data dilakukan dengan Focus Group Discussion (FGD), observasi, dan survei. Metode survei yang digunakan ialah wawancara dan pengisian kuisioner dengan skala likert +1 hingga +5 . Skala +1 menunjukkan bahwa responden sangat tidak setuju, skala +2 menunjukkan bahwa responden tidak setuju, skala +3 menunjukkan bahwa responden netral, skala +4 menunjukkan bahwa responden setuju, dan skala +5 menunjukkan bahwa responden sangat setuju. Variabel penelitian terdiri dari sumber daya ekonomi $\left(\mathrm{X}_{1}\right)$, sumber daya lingkungan $\left(\mathrm{X}_{2}\right)$, sumber daya sosial $\left(\mathrm{X}_{3}\right)$, sumber daya manusia (Z), dan aspek kerentanan usaha ternak sapi perah (Y). Variabel dan indikator tersebut diuraikan pada Tabel 1.

\section{Tabel 1. Variabel dan indikator penelitian}

\begin{tabular}{|c|c|c|}
\hline \multirow{2}{*}{$\begin{array}{c}\text { Variabel } \\
\text { Sumber daya ekonomi }\left(\mathrm{X}_{1}\right)\end{array}$} & \multicolumn{2}{|l|}{ Indikator } \\
\hline & 1. Pendidikan formal peternak & $\mathrm{X}_{1.1}$ \\
\hline & 2. Pendidikan non-formal peternak & $\mathrm{X}_{1.2}$ \\
\hline & 3. Tingkat keterlibatan tenaga kerja keluarga & $\mathrm{X}_{1.3}$ \\
\hline & 4. Status kesehatan keluarga & $\mathrm{X}_{1.4}$ \\
\hline & 5. Status konsumsi gizi keluarga & $\mathrm{X}_{1.5}$ \\
\hline & 6. Tingkat kenyamanan rumah tempat tinggal & $\mathrm{X}_{1.6}$ \\
\hline & 7. Kesempatan memanfaatkan waktu luang untuk rekreasi & $\mathrm{X}_{1.7}$ \\
\hline & 8. Tingkat kredibilitas peternak & $\mathrm{X}_{1.8}$ \\
\hline \multirow[t]{6}{*}{ Sumber daya lingkungan $\left(\mathrm{X}_{2}\right)$} & 1. Tingkat pencemaran udara & $\mathrm{X}_{2.1}$ \\
\hline & 2. Tingkat pencemaran tanah & $\mathrm{X}_{2.2}$ \\
\hline & 3. Tingkat pencemaran air & $\mathrm{X}_{2.3}$ \\
\hline & 4. Tingkat pencemaran suara & $\mathrm{X}_{2.4}$ \\
\hline & 5. Pemanfaatan limbah kotoran ternak untuk pupuk & $\mathrm{X}_{2.5}$ \\
\hline & 6. Pemanfaatan limbah pertanian untuk pakan ternak & $\mathrm{X}_{2.6}$ \\
\hline \multirow[t]{9}{*}{ Sumber daya sosial $\left(\mathrm{X}_{3}\right)$} & 1. Peranan peternak dalam organisasi masyarakat & $\mathrm{X}_{3.1}$ \\
\hline & 2. Hubungan kerjasama dengan peternak lain & $\mathrm{X}_{3.2}$ \\
\hline & 3. Hubungan dengan aparat desa & $\mathrm{X}_{3.3}$ \\
\hline & 4. Hubungan dengan petugas kesehatan ternak & $\mathrm{X}_{3.4}$ \\
\hline & 5. Hubungan dengan dinas peternakan & $\mathrm{X}_{3.5}$ \\
\hline & 6. Hubungan dengan perusahaan pakan ternak & $\mathrm{X}_{3.6}$ \\
\hline & 7. Hubungan dengan tenaga penyuluh & $\mathrm{X}_{3.7}$ \\
\hline & 8. Hubungan dengan lembaga keuangan & $\mathrm{X}_{3.8}$ \\
\hline & 9. Hubungan dengan kelembagaan peternakan & $\mathrm{X}_{3.9}$ \\
\hline \multirow[t]{4}{*}{ Sumber daya manusia $(\mathrm{Z})$} & 1. Pengetahuan dan keterampilan dalam usaha ternak & $\mathrm{Z}_{1.1}$ \\
\hline & 2. Status kesehatan peternak & $\mathrm{Z}_{1.2}$ \\
\hline & 3. Motivasi peternak & $\mathrm{Z}_{1.3}$ \\
\hline & 4. Kemampuan peternak dalam penggunaan bahasa sehari-hari & $\mathrm{Z}_{1.4}$ \\
\hline \multirow[t]{7}{*}{ Aspek kerentanan usaha ternak $(\mathrm{Y})$} & 1. Musim (kondisi tidak pasti) & $\mathrm{Y}_{1.1}$ \\
\hline & 2. Kemanan ternak (pencurian) & $\mathrm{Y}_{1.2}$ \\
\hline & 3. Penyakit dan kesehatan ternak & $\mathrm{Y}_{1.3}$ \\
\hline & 4. Fluktuasi harga jual susu segar & $\mathrm{Y}_{1.4}$ \\
\hline & 5. Kebijakan pemerintah & $\mathrm{Y}_{1.5}$ \\
\hline & 6. Kebijakan kelembagaan peternakan & $\mathrm{Y}_{1.6}$ \\
\hline & 7. Moralitas peternak di dalam kelembagaan & $\mathrm{Y}_{1.7}$ \\
\hline
\end{tabular}


Berdasarkan variabel dan indikator penelitian pada Tabel 1, maka model hubungan sesama variabel ditunjukkan pada Gambar 1:

Data dianalisis dengan menggunakan metode Partial Least Square (PLS). Metode PLS terdiri dari dua macam pengujian, yaitu outer model dan inner model. Pengujian outer model meliputi uji indikator (nilai outer loading), nilai Average Variance Extracted (AVE), nilai Composite Reliability (CR), nilai Cronbach's Alpha (CA), dan nilai $R$ Square $\left(\mathrm{R}^{2}\right)$. Pengujian inner model meliputi nilai koefisien parameter, nilai t-statistik, dan nilai koefisien determinasi.

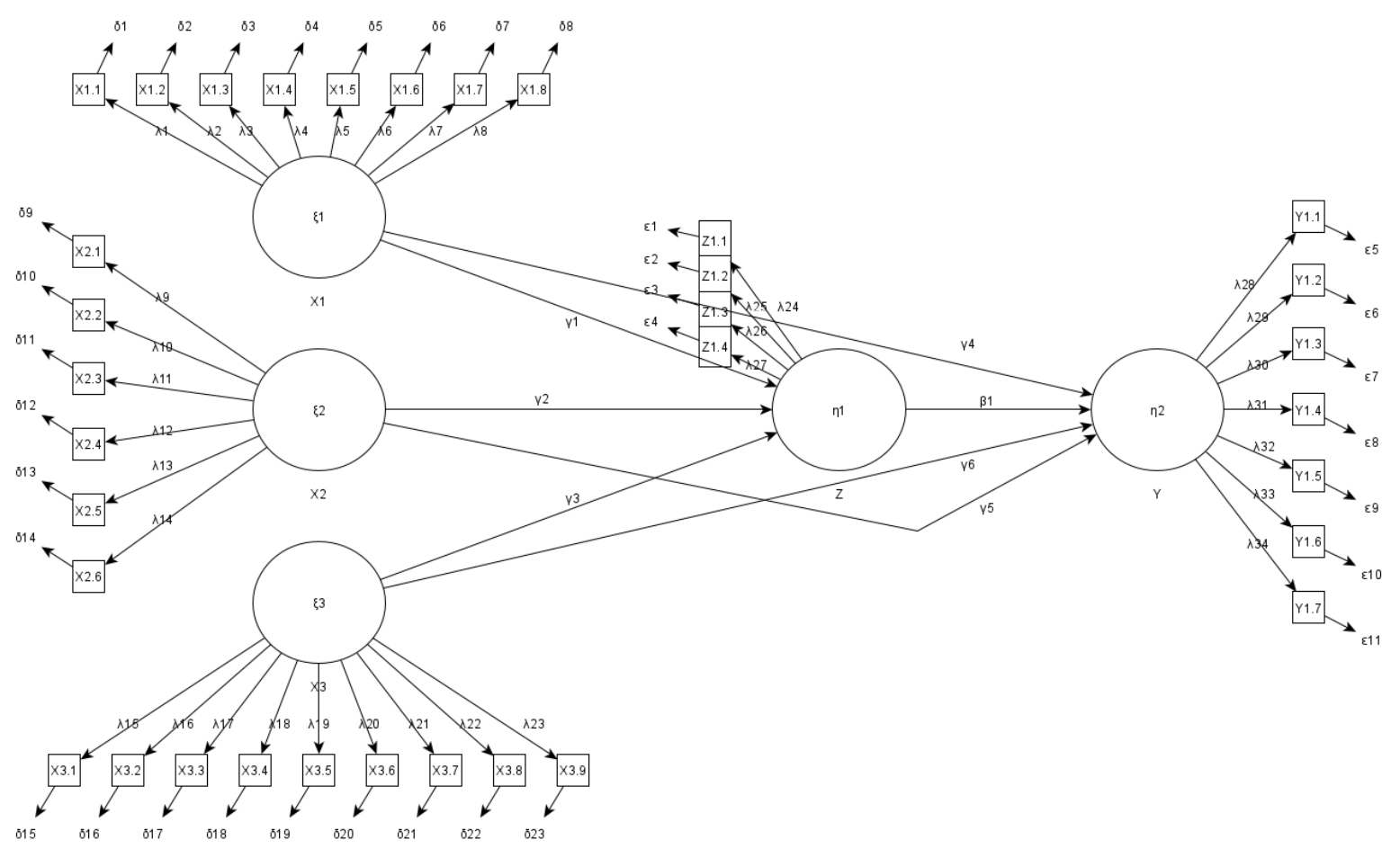

Gambar 1. Model hubungan variabel penelitian

\section{HASIL DAN PEMBAHASAN}

Kelembagaan peternakan sapi perah Kelompok Usaha Bersama (KUB) Tirtasari Kresna Gemilang berdiri tahun 2017 dan berkantor di Desa Ngabab, Kecamatan Pujon, Kabupaten Malang. Secara topografi, Desa Ngabab berada di ketinggian 1.200 meter di atas permukaan laut dengan suhu $8-18^{\circ} \mathrm{C}$, sehingga ideal untuk pengembangan usaha ternak sapi perah di Kabupaten Malang. Potensi tersebut juga didukung oleh berbagai sumber daya yang tersedia, diantaranya adalah ketersediaan hijauan pakan yang melimpah baik dari jenis rerumputan maupun limbah pertanian.

Limbah pertanian yang melimpah sebagai dampak dari Desa Ngabab sebagai pusat transaksi sayur-mayur terbesar di wilayah Pujon. Potensi lain Desa Ngabab juga sebagai jalur utama lalu lintas darat (jalur pegunungan) penghubung Kabupaten Malang dengan Kabupaten Kediri. Berbagai sumber daya tersebut berperan penting terhadap keberlanjutan usaha ternak sapi perah. Amam dan Soetriono (2020) menyebutkan bahwa sumber daya memiliki peranan penting terhadap pengembangan usaha ternak. Sumber daya tersebut diantaranya ialah sumber daya finansial, teknologi, dan fisik (Amam et al., $2019^{\mathrm{e}}$ ) serta sumber daya ekonomi, lingkungan, dan sosial (Amam et al., 2019 ).

\section{PENGUJIAN OUTER MODEL}

Kriteria pengujian outer model dengan menggunaan metode Partial Least Square (PLS) terdiri dari uji indikator (nilai outer loading), nilai Average Variance Extracted (AVE), nilai Composite Reliability (CR), nilai Cronbach's Alpha (CA), dan nilai $R$ Square $\left(\mathrm{R}^{2}\right)$. Hasil uji tersebut ditunjukkan di dalam Tabel 2 dan Tabel 3: 
Tabel 2. Hasil uji indikator

\begin{tabular}{|c|c|c|c|c|c|}
\hline Indikator & $\mathbf{X}_{1}$ & $\mathbf{X}_{2}$ & $\mathbf{X}_{3}$ & $\mathbf{Z}$ & $\mathbf{Y}$ \\
\hline $\mathrm{X}_{1.4}$ & 0,669 & & & & \\
\hline $\mathrm{X}_{1.5}$ & 0,822 & & & & \\
\hline $\mathrm{X}_{2.1}$ & & 0,897 & & & \\
\hline $\mathrm{X}_{2.4}$ & & 0,736 & & & \\
\hline$X_{3.1}$ & & & 0,550 & & \\
\hline$X_{3.2}$ & & & 0,753 & & \\
\hline$X_{3.3}$ & & & 0,781 & & \\
\hline $\mathrm{X}_{3.4}$ & & & 0,602 & & \\
\hline $\mathrm{X}_{3.6}$ & & & 0,754 & & \\
\hline $\mathrm{X}_{3.7}$ & & & 0,516 & & \\
\hline $\mathrm{X}_{3.8}$ & & & 0,636 & & \\
\hline$X_{3.9}$ & & & 0,683 & & \\
\hline $\mathrm{Z}_{1.2}$ & & & & 0,908 & \\
\hline $\mathrm{Z}_{1.3}$ & & & & 0,809 & \\
\hline$Y_{1.4}$ & & & & & 0,761 \\
\hline $\mathrm{Y}_{1.5}$ & & & & & 0,805 \\
\hline$Y_{1.6}$ & & & & & 0,898 \\
\hline $\mathrm{Y}_{1.7}$ & & & & & 0,858 \\
\hline
\end{tabular}

Keterangan: nilai outer loading setelah menghilangkan indikator tidak valid (valid $\geq 0,500$ )

Tabel 3. Hasil uji model

\begin{tabular}{|ccccc|}
\hline Indikator & $\mathbf{A V E}$ & $\mathbf{C R}$ & $\mathbf{C A}$ & $\mathbf{R}^{\mathbf{2}}$ \\
$\mathrm{X}_{1}$ & 0,648 & 0,789 & 0,754 & \\
$\mathrm{X}_{2}$ & 0,671 & 0,803 & 0,778 & \\
$\mathrm{X}_{3}$ & 0,829 & 0,928 & 0,848 & 0,103 \\
$\mathrm{Z}$ & 0,705 & 0,822 & 0,792 & 0,295 \\
$\mathrm{Y}$ & 0,812 & 0,936 & 0,869 & \\
\hline
\end{tabular}

\section{PENGUJIAN INNER MODEL}

Kriteria pengujian inner model dengan menggunaan metode Partial Least Square (PLS) terdiri dari nilai koefisien parameter, nilai t-statistik, dan nilai koefisien determinasi. Hasil pengujian tersebut ditunjukkan di dalam Tabel 4:

\section{DAMPAK SUMBER DAYA TERHADAP SUMBER DAYA MANUSIA (SDM) PETERNAK}

Sumber Daya Manusia (SDM) peternak sapi perah dipengaruhi oleh sumber daya ekonomi, lingkungan, dan sosial sebesar 10,3\%. Widiarso dan Mubarokah (2019) menyatakan bahwa faktor pendidikan dan umur berpengaruh sangat signifikan terhadap respon peternak, sedangkan peningkatan respon peternak dipengaruhi oleh pendidikan, umur, pengalaman beternak, dan jumlah kepemilikan ternak. Suresti et al. (2013) menambahkan bahwa tingkat pendidikan dan curahan waktu kerja peternak memberikan kontribusi sebesar 62,9\%. Darodjah et al. (2014) juga menyebutkan bahwa kegiatan pengabdian kepada masyarakat yang dilakukan oleh sivitas akademik, baik oleh dosen dan/atau mahasiswa, dapat meningkatkan SDM peternak.

Sumber daya ekonomi berpengaruh positif terhadap SDM peternak sapi perah namun tidak signifikan. Hal tersebut menunjukkan bahwa sumber daya ekonomi peternak sapi perah di KUB Tirtasari Kresna Gemilang memberikan pengaruh terhadap tingkat kesehatan dan motivasi peternak. Tingkat kesehatan dan konsumsi gizi keluarga peternak sebagai indikator sumber daya ekonomi, memberikan dampak pada tingkat kesehatan peternak sapi perah meskipun tidak signifikan. Motivasi peternak untuk melanjutkan usaha ternak sapi perah meningkat seiring dengan kesehatan peternak dan kecukupan gizi keluarga meskipun tidak signifikan. 


\section{Tabel 4. Hasil uji struktural}

\begin{tabular}{|c|c|c|}
\hline Pengujian & Hasil Uji & Keterangan \\
\hline $\begin{array}{l}\text { Koefisien Determinasi }\left(\mathrm{R}^{2}\right) \\
\begin{aligned} \text { a. } & \text { Sumber daya manusia } \\
\text { b. } & \text { Aspek kerentanan usaha ternak }\end{aligned}\end{array}$ & $\begin{array}{l}0,103 \\
0,295\end{array}$ & $\begin{array}{l}\text { total pengaruh } 10,3 \% \\
\text { total pengaruh } 29,5 \%\end{array}$ \\
\hline $\begin{array}{ll}\text { t-statistik } \\
\begin{aligned} \text { a. } & X_{1} \rightarrow Z \\
\text { b. } & X_{2} \rightarrow Z \\
\text { c. } & X_{3} \rightarrow Z \\
\text { d. } & X_{1} \rightarrow Y \\
\text { e. } & X_{2} \rightarrow Y \\
\text { f. } & X_{3} \rightarrow Y \\
\text { g. } & Z \rightarrow Y\end{aligned}\end{array}$ & $\begin{array}{c}0,050 \\
-0,078 \\
-0,324 \\
0,249 \\
0,317 \\
-0,122 \\
0,179\end{array}$ & $\begin{array}{l}+ \\
- \\
- \\
+ \\
+ \\
- \\
+\end{array}$ \\
\hline $\begin{array}{cl}\text { Koefisien Parameter } \\
\begin{array}{cl}\text { a. } & \mathrm{X}_{1} \rightarrow \mathrm{Z} \\
\text { b. } & \mathrm{X}_{2} \rightarrow \mathrm{Z} \\
\text { c. } & \mathrm{X}_{3} \rightarrow \mathrm{Z} \\
\text { d. } & \mathrm{X}_{1} \rightarrow \mathrm{Y} \\
\text { e. } & \mathrm{X}_{2} \rightarrow \mathrm{Y} \\
\text { f. } & \mathrm{X}_{3} \rightarrow \mathrm{Y} \\
\text { g. } & \mathrm{Z} \rightarrow \mathrm{Y}\end{array}\end{array}$ & $\begin{array}{l}0,465 \\
0,715 \\
3,295 \\
2,501 \\
3,351 \\
1,247 \\
1,848\end{array}$ & $\begin{array}{l}\text { tidak signifikan } \\
\text { tidak signifikan } \\
\text { signifikan } \\
\text { signifikan } \\
\text { signifikan } \\
\text { tidak signifikan } \\
\text { signifikan }\end{array}$ \\
\hline
\end{tabular}

Keterangan: nilai $\mathrm{t}$-tabel $=1,653$; signifikan $=\mathrm{t}$-statistik $\geq \mathrm{t}$-tabel

Pendapatan petani (peternak) sangat erat kaitannya dengan tingkat kesejahteraan (Rahmah, 2013). Nilai Tukar Pendapatan Rumah Tangga Pedesaan (NTPRP) merupakan indikator untuk menentukan tingkat kesejahteraan masyarakat petani (peternak). Kontribusi pendapatan dari usaha ternak sapi perah terhadap total pendapatan peternak sebesar 46,71\%. Kondisi tersebut menurut Suresti et al. (2013) berbanding terbalik jika fakta menunjukkan bahwa kapasitas SDM dalam usaha ternak sangat rendah sehingga menimbulkan dampak yang kurang menguntungkan, lemahnya posisi daya tawar peternak, minimnya penggunaan SDM dan tenaga kerja professional, rendahnya keterampilan, serta kurangnya motivasi peternak dalam pengembangan usaha ternak.

Sumber daya lingkungan berpengaruh negatif terhadap SDM peternak sapi perah namun tidak signifikan. Hal tersebut menunjukkan bahwa sumber daya lingkungan peternak sapi perah di KUB Tirtasari Kresna Gemilang memberikan pengaruh terhadap kesehatan dan motivasi peternak. Tingkat pencemaran udara dan tingkat pencemaran suara sebagai indikator sumber daya lingkungan, memberikan pengaruh pada tingkat kesehatan peternak sapi perah meskipun tidak signifikan. Motivasi peternak untuk melanjutkan usaha ternak sapi perah menurun seiring dengan adanya tingkat pencemaran udara dan tingkat pencemaran suara meskipun tidak signifikan.

Dampak negatif yang ditimbulkan dari pengembangan usaha ternak sapi perah bersumber dari kotoran (limbah) sapi perah berupa gas methan sebagai bahan pencemar udara, juga sebagai media tumbuh dan berkembangnya mikroorganisme yang dapat mengganggu kesehatan lingkungan dan ekosistem, serta munculnya bau yang mengganggu kenyamanan umat manusia (Widyastuti et al., 2013). Linggotu et al. (2016) menyebutkan bahwa limbah (kotoran) usaha peternakan dapat menimbulkan permasalahan lingkungan di sekitar pemukiman penduduk jika tidak dikelola dengan baik. Hal tersebut dapat menganggu kesehatan peternak dan menurunkan motivasi peternak sapi perah.

Sumber daya sosial berpengaruh negatif dan signifikan terhadap SDM peternak sapi perah. Hal tersebut menunjukkan bahwa sumber daya sosial peternak sapi perah di KUB Tirtasari Kresna Gemilang memberikan pengaruh terhadap kesehatan dan motivasi peternak. Peranan peternak di dalam organisasi masyarakat, hubungan dengan sesama peternak sapi perah, hubungan dengan apparat desa, hubungan dengan petugas kesehatan ternak, hubungan dengan perusahaan pakan ternak, hubungan dengan tenaga penyuluh, hubungan 
dengan lembaga keuangan, dan hubungan dengan kelembagaan peternak (KUB Tirtasari Kresna Gemilang) sebagai indikator sumber daya sosial memberikan pengaruh pada tingkat kesehatan peternak dan motivasi di dalam usaha ternak. Pengaruh tersebut signikan (penting) terhadap SDM peternak sapi perah.

Peran serta kontribusi masyarakat sangat menentukan arah dan percepatan pencapaian tujuan dalam pembangunan, partisipasi kelompok masyarakat yang memiliki kesamaan harapan, tujuan hidup, dan profesi menjadi pemersatu atau kekuatan sosial (social power) (Solikin et al., 2018). Putra et al. (2017) menjelaskan bahwa konsep kebijakan pembangunan peternakan telah bergeser dari paradigma sentralistik menuju partisipatoris. Konsep tersebut diwujudkan dalam bentuk kelompok-kelompok ternak/peternak yang merupakan perwujudan modal sosial untuk pembangunan nasional dan kesejahteraan masyarakat.

\section{DAMPAK SUMBER DAYA TERHADAP ASPEK KERENTANAN USAHA TERNAK}

Aspek kerentanan usaha ternak sapi perah dipengaruhi oleh sumber daya ekonomi, lingkungan, sosial, dan SDM peternak sebesar 29,5\%. Amam dan Harsita (2019) mendefinisikan aspek kerentanan adalah sebuah kondisi bahaya, baik bahaya alam maupun bahaya buatan, yang dapat menimbulkan risiko kerugian pada usaha ternak. Salah satu risiko tersebut dijelaskan oleh Anggraini dan Putra (2017) yang menyebutkan bahwa ialah rendahnya Indeks Daya Dukung (IDD) wilayah terhadap ketersediaan sumber hijauan pakan ternak. IDD hijauan pakan $>2$ merupakan nilai ideal untuk pengembangan usaha ternak.

Sumber daya ekonomi berpengaruh positif dan signifikan terhadap aspek kerentanan usaha ternak sapi perah. Hal tersebut menunjukkan bahwa sumber daya ekonomi peternak sapi perah di KUB Tirtasari Kresna Gemilang memberikan pengaruh penting terhadap fluktuasi harga jual susu segar, kebijakan pemerintah, kebijakan kelompok, dan moralitas peternak di dalam kelompok. Semakin tinggi sumber daya ekonomi, maka semakin tinggi pula aspek kerentanan usaha ternak sapi perah.
Sumber daya lingkungan berpengaruh positif dan signifikan terhadap aspek kerentanan usaha ternak sapi perah. Hal tersebut menunjukkan bahwa sumber daya lingkungan peternak sapi perah di KUB Tirtasari Kresna Gemilang memberikan pengaruh penting terhadap fluktuasi harga jual susu segar, kebijakan pemerintah, kebijakan kelompok, dan moralitas peternak di dalam kelompok. Semakin tinggi sumber daya lingkungan, maka semakin tinggi pula aspek kerentanan usaha ternak sapi perah.

Sumber daya sosial berpengaruh negatif terhadap aspek kerentanan usaha ternak sapi perah namun tidak signifikan. Semakin tinggi sumber daya sosial, maka semakin rendah aspek kerentanan usaha ternak sapi perah, meskipun pengaruh tersebut tidak begitu penting. Rendahnya aspek kerentanan usaha ternak sapi perah di KUB Tirtasari Kresna Gemilang salah satunya disebabkan oleh pengaruh performa kelembagaan. Amam dan Soetriono (2019) menyebutkan bahwa salah satu manfaat kelembagaan ialah dapat menekan aspek risiko bisnis.

\section{PENGARUH SUMBER DAYA MANUSIA TERHADAP ASPEK KERENTANAN USAHA TERNAK}

Aspek kerentanan usaha ternak sapi perah dipengaruhi oleh SDM peternak, sumber daya ekonomi, lingkungan, dan sosial sebesar $29,5 \%$, sedangkan sisanya sebesar $70,5 \%$ dipengaruhi oleh faktor lain yang tidak terdapat di dalam model. Amam dan Harsita $\left(2019^{a}\right)$ menyebutkan bahwa aspek kerentanan usaha ternak berpengaruh negatif dan signifikan terhadap pengembangan usaha ternak, sehingga aspek kerentanan usaha ternak harus menjadi perhatian stakeholder mengingat dampaknya dapat menghambat pengembangan usaha ternak.

Sumber Daya Manusia (SDM) peternak berpengaruh positif dan signifikan terhadap aspek kerentanan usaha ternak sapi perah. Hal tersebut dapat menjadi ancaman dan tantangan bagi keberlanjutan usaha ternak sapi perah di KUB Tirtasari Kresna Gemilang. Artinya, semakin tinggi SDM peternak yang berkaitan dengan kesehatan peternak dan motivasi peternak, maka semakin tinggi halangan dan 
tantangan usaha ternak yang berkaitan dengan aspek kerentanan.

Keberlanjutan usaha ternak sapi perah mengambil peran penting dari kesehatan peternak dan motivasi peternak. Motivasi peternak terhadap usaha ternak sapi perah tetap terjaga sebagai dampak dari adanya kelembagaan peternak. Widiarso dan Mubarokah (2019) menjelaskan bahwa kelembagaan sebagai wadah penyuluhan memberikan dampak yang efektif terhadap perubahan sikap peternak. Ketergantungan kelembagaan atau koperasi terhadap Industri Pengolahan Susu (IPS) sangat tinggi. Hal tersebut disebabkan karena koperasi hanya mampu melakukan pengolahan susu segar dengan skala kecil dan kelembagaan peternak masih sedikit yang berupaya mengolah susu segar secara mandiri. Penyerapan dan pemanfaatan Susu Segar Dalam Negeri (SSDN) oleh IPS masih mendominasi bisnis pemasaran susu sapi perah rakyat.

Penyerapan dan pemanfaatan SSDN oleh IPS ditengarai semakin rendah sebagai dampak dari perubahan Peraturan Menteri Pertanian Respublik Indonesia. Hal tersebut dapat menyebabkan terganggunya bisnis usaha ternak sapi perah, sehingga jumlah peternak sapi perah semakin sedikit dengan populasi ternak sapi perah yang semakin rendah, serta sangat memungkinkan akan menambah jumlah penggangguran di pedesaan yang semakin meningkat. Perubahan tersebut juga dapat memperlemah posisi daya tawar peternak sapi perah jika dibandingkan dengan susu segar impor. Lemahnya posisi daya tawar tersebut diantaranya harga jual susu segar lokal lebih mahal, rendahnya kualitas susu segar lokal, dan keterjaminan (kuantitas) yang masih tidak stabil.

\section{KESIMPULAN}

Aspek kerentanan usaha ternak sapi perah dipengaruhi oleh sumber daya ekonomi, lingkungan, dan sosial sebesar 29,5\%. Sumber daya ekonomi dan lingkungan berpengaruh positif dan signifikan terhadap aspek kerentanan usaha ternak sapi perah masingmasing sebesar 0,249 dan 0,317, sedangkan sumber daya sosial berpengaruh negatif namun tidak signifikan.

\section{UCAPAN TERIMAKASIH}

Tim penulis dedikasikan ucapan terimakasih kepada: 1) Lembaga Penelitian dan Pengabdian kepada Masyarakat (LP2M) Universitas Jember; 2) KUB Tirtasari Kresna Gemilang; 3) Kelompok Riset (KeRis) Integrated Farming Business for Large Ruminant (IFSLR); 4) Kelompok Riset A2P (Agribisnis dan Agroindustri Peternakan); 5) Program Studi Peternakan, Fakultas Pertanian, Universitas Jember, 6) mahasiswa peternakan yang terlibat di dalam jalannya proses penelitian tahun anggaran 2018-2021.

\section{DAFTAR PUSTAKA}

Amam, Fanani Z, Hartono B, and Nugroho BA. $2019^{a}$. Identification of resources in the system of broiler farming business. Jurnal Ilmu Ternak dan Veteriner. 24 (3): 135142.

DOI: http://dx.doi.org/10.14334/jitv.v24.3.1927

Amam, Fanani Z, Hartono B, and Nugroho BA. $2019^{\mathrm{b}}$. Usaha ternak ayam pedaging sistem kemitraan pola dagang umum: pemetaan sumber daya dan model pengembangan. Sains Peternakan: Jurnal Penelitian Ilmu $\begin{array}{lll}\text { Peternakan. } 17 & \text { (2): 5-11. DOI: }\end{array}$ http://dx.doi.org/10.20961/sainspet.v17i2. 26892.

Amam, Jadmiko MW, Harsita PA, dan Poerwoko MS. 2019 . Model pengembangan usaha ternak sapi perah berdasarkan faktor aksesibilitas sumber daya. Jurnal Sain Peternakan Indonesia. 14 (1): 61-69. DOI: https://doi.org/10.31186/jspi.id.14.1.61$\underline{69}$.

Amam, Jadmiko MW, Harsita PA, Widodo N, dan Poerwoko MS. 2019d ${ }^{\text {. Sumber daya }}$ internal peternak sapi perah dan pengaruhnya terhadap dinamika kelompok dan konteks kerentanan. Jurnal Ilmiah Peternakan Terpadu. 7 (1): 192-200.

Amam, Jadmiko MW, Harsita PA, dan Yulianto R. 2019 ${ }^{\mathrm{e}}$. Internal resources of dairy cattle farming business and their effect on institutional performance and business development. Jurnal Animal Production. 21 (3): 157-166. DOI: http://doi.org/10.20884/1.jap.2019.21.3.73 $\underline{8}$. 
Amam dan Harsita PA. 2019 ${ }^{\mathrm{a}}$. Aspek kerentanan usaha ternak sapi perah di Kabupaten Malang. Agrimor: Jurnal Agribisnis Lahan Kering. 4 (2): 26-28. DOI:

https://doi.org/10.32938/ag.v4i2.663.

Amam dan Harsita PA. 2019 . Efek domino performa kelembagaan aspek risiko, dan pengembangan usaha terhadap SDM peternak sapi perah. Sains Peternakan: Jurnal Penelitian Ilmu Peternakan. 17 (1): 5-11. DOI: http://dx.doi.org/10.20961/sainspet.v\%vi \%i.24266.

Amam dan Harsita PA. $2019^{c}$. Tiga pilar usaha ternak: breeding, feeding, and management. Jurnal Sain Peternakan Indonesia. 14 (4): 431-439. DOI: https://doi.org/10.31186/jspi.id.14.4.431439.

Amam dan Soetriono. 2019. Evaluasi performa kelembagaan peternak sapi perah berdasarkan aspek risiko bisnis dan pengembangan usaha. Jurnal Ilmu dan Teknologi Peternakan Tropis. 5 (3): 8-13.

Amam dan Soetriono. 2020. Peranan sumber daya terhadap SDM peternak dan pengembangan usaha ternak sapi perah di Kawasan Peternakan Sapi Perah Nasional (KPSPN). Jurnal Peternakan Indonesia. $22 \quad$ (1): 1-10. DOI: https://doi.org/10.25077/jpi.22.1.110.2020.

Anggraini N dan Putra RA. 2017. Analisis potensi wilayah dalam pengembangan peternakan sapi potong di Kecamatan Sijunjung Kabupaten Sijunjung. Jurnal Agrifo. 2 (2): 82-100.

Darodjah S, Indrijani H, Cipto DB, Anang A, dan Arifin J. 2014. Peningkatan kualitas SDM peternak sapi rancah Kawasan buffer zone hutan melalui pembentukan village breeding center dan konsep exsitu farming dalam pola pembibitan di Jawa Barat. Dhramakarya: Jurnal Aplikasi Inpteks untuk Masyarakat. 3 (2): 73-77. DOI: https://doi.org/10.24198/dharmakarya.v3i $\underline{2.8351}$.

Linggotu LO, Paputungan U, dan Polii B. 2016. Pengolaan limbah kotoran ternak dalam upaya pencegahan pencemaran lingkungan di Kota Kotamobago. Jurnal Zootek. 36 (1): 226-237.

Putra RARS, Ariyadi B, Kurniawati N, dan Haryadi FT. 2017. Pengaruh modal sosial terhadap tingkat kesejahteraan rumah tangga peternak: studi kasus pada kelompok peternak ayam kampung Ngudi Mulyo, Gunung Kidul. Buletin Peternakan. 41 (3): 349-354. DOI: https://doi.org/10.21059/buletinpeternak.v 41i3.18135.

Rahmah UIL. 2013. Analisis tingkat kesejahteraan peternak sapi perah di Provinsi Jawa Tengah. Jurnal Ilmu Pertanian dan Peternakan. 1 (3): 78-99.

Solikin N, Hartono B, Fanani Z, dan Iksan MN. 2018. Tingkat partisipasi dan kesejahteraan peternak sapi potong di Kabupaten Kediri. Jurnal Musamba. 3 (2): 81-85. DOI: https://doi.org/10.29407/nusamba.v3i2.12 543.

Suresti A, Wati R, dan Indrayani I. 2013. Analisis potensi sumber daya manusia untuk pengembangan usaha peternak sapi potong di Kabupaten Pesisi Selatan. Jurnal Peternakan Indonesia. 15 (1): 7-16.

Widiarso BP dan Mubarokah WW. 2019. Respon peternak terhadap pencegahan dan pengobatan penyakit cacing Gastrointestinal pada kambing di Desa Klopo Kecamatan Tegalrejo Kabupaten Magelang. Jurnal Ilmu Peternakan dan Veteriner Tropis. 9 (2): 76-82. DOI: https://doi.org/10.30862/jipvet.v9i2. $\underline{68}$

Widyastuti FR, Purwanto, dan Hadiyanto. 2013. Upaya pengelolaan lingkungan usaha peternakan sapi di Kawasan Usaha Tani Terpadu Bangka Botanical Garden Pangkalpinang. Prosiding Seminar Nasional Pengelolaan Sumber Daya Alam dan Lingkungan. Semarang. 81-85. 